\title{
WRITING THE SELF IN RURAL MALI: DOMESTIC ARCHIVES AND GENRES OF PERSONAL WRITING
}

\author{
Aïssatou Mbodj-Pouye
}

Recent studies of literacy in colonial and post-colonial Africa have highlighted cases of sub-elite individuals taking hold of literacy for their own needs (Barber 2006). The study presented here, based on ethnographic research into writing practices in one village in southern Mali, is located even closer to the 'grassroots' level, since the writers under consideration have no standing as local intellectuals. As only a minority of villagers have access to literacy, those who went to primary school or attended literacy classes may act as brokers for their illiterate peers, but their social identity is not in the first instance defined by their literate status. Their writing practices are not addressed to an intellectual sphere of exchange. Writing appears prominently as a form of management of one's family and one's life. On a daily basis, it shapes many of the activities people engage in, and, in a diachronic perspective, it is one of the lines standing out as meaningful for some of the biographic trajectories.

This article investigates how literacy plays a role in the emergence of a new private sphere in contemporary Mali. Writing and subjectivity are issues commonly associated in European history, linking autobiography and some literary genres, such as the novel, to the emergence of 'modern' self-consciousness (Chartier 1986). Ordinary writing practices, such as diary keeping, have also been investigated as sites from which to get an understanding of these processes. For non-Western societies, one approach to this issue has been to take a critical look at the way colonized subjects used genres of self-writing established in the West. Even if they cope with these imposed models and eventually reshape them, self-writing appears, in this vein, as a set of relatively constrained forms (Chakrabarty 1992; Comaroff and Comaroff 1991). Case studies of diary keeping in Africa have furthered these considerations and highlighted the different meanings these practices, learnt in missionary schools, may take on (Miescher 2006; Watson 2006).

The perspective adopted here is slightly different. In the cotton-producing region, the encounter with literacy and its modern uses is not often experienced through personal genres; instead, it emerges from the documentary practices and paperwork that fuel colonial and post-colonial governmentality (for a telling inventory of administrative documents kept in a Cameroonian village, see Zeitlyn 2005). Thus, personal practices arise in defence against or as responses to the pressure of institutions more than as deliberate attempts to engage in self-writing.

\footnotetext{
AÏSSATOU MBODJ-POUYE is Research Fellow at the CNRS (Centre national de la recherche scientifique), based at the Centre d'études des mondes africains in Paris. Her monograph on paths to literacy and writing practices in the cotton-growing region of Mali will appear in 2013 (ENSEditions, Lyon). Her current research project focuses on memory, documentary traces and subjectivity in France among West African migrants, as well as in Senegal. Email: mbodj@cnrs.fr
} 
In such contexts, the issue of genre becomes problematic, as those practices do not follow established forms, but rather find their ways by borrowing from several models in a dynamic process of appropriation.

Thus this article investigates practices whose characterization as writings of the self is not straightforward, placing particular focus on notebooks made out of pieces collected from different sources. It might sound paradoxical to explore what 'making the self' means through practices so remote from what would qualify immediately as self-writing. But, precisely because they emerge without stable models of self-writing, these practices are an interesting starting point for exploring subjectivities when a space for self-fashioning is not given as such.

To begin with, I shall provide an insight into writing practices in the village and discuss the local notions of the private and the personal. Then I shall explore these practices by focusing on two villagers and one practice-keeping a notebookwhose various forms I shall detail. Finally, I shall return to the notion of the personal, elaborating on the anthropological meanings of these practices as spaces where writers experiment with several figures of the self and bring them together.

\section{THE 'USES OF LITERACY': FROM COLLECTIVE TO PRIVATE}

Richard Hoggart's The Uses of Literacy highlights the interest of investigating the uses of reading and writing in a community (Hoggart 1957). His phrase also conveys the idea that effective uses might differ from the intentions of educationists and promoters of literacy campaigns: however generous they may be, they may miss the actual interests of the subjects of these educative projects. This perspective has been central to the agenda of New Literacy Studies (see, for instance, Street 2001). In presenting the context of my research, I shall highlight the gap between the community-oriented development of literacy and the observed privilege accorded to personal and private practices.

\section{The promotion of literacy: writing for the community}

This article is based on an ethnographic study of literacy practices in the cottongrowing region of Mali. ${ }^{1}$ I have chosen this region because important functional literacy campaigns have been conducted there. My research focused on one village near the town of Fana, in the northern part of this region, where Bamanan is the first language of the majority.

Islamic uses of literacy in Arabic have long been part of the history of the area. The colonial imposition of writing in French brought new uses of writing, and of schooling, which were developed throughout the twentieth century. But the first massive diffusion of literacy programmes in the region took place in the 1970s. At first, functional literacy campaigns in Bamanan were organized by the

\footnotetext{
${ }^{1}$ This research was a part of my $\mathrm{PhD}$ in Sociology and Anthropology at University Lyon 2, with most fieldwork conducted between 2002 and 2004 ( 8 months), completed by fieldtrips in 2007 and 2009. I rely on in-depth interviews and observations of writing practices. I also conducted a basic survey among the 1,500 inhabitants of the village. With no Malian background (I am French and Senegalese), I learnt Bamanan for this research.
} 
governmental organization in charge of literacy, the DNAFLA (Direction Nationale de l'Alphabétisation Fonctionnelle et de la Linguistique Appliquée); then in the second half of the 1970s the CMDT (Compagnie Malienne pour le Développement des Textiles) became involved. The CMDT had its own interests in developing literacy classes, as it was trying to carry out a major organizational change that entailed the delegation of many tasks to local villagers' associations. This process required that some villagers be literate in Bamanan, so that they could keep records and perform a series of tasks requiring accounting, measurement, reading and writing (a record of the early development of the programme is available in Dumont 1973 and an analysis is provided in Turritin 1989). In the village where I worked, a literacy centre was opened in 1971 as part of the state-sponsored literacy campaign in Bamanan. Then the CMDT ran its own classes until the mid-1980s. At that time, villagers who had became literate through the literacy classes were joined by the first school-leavers from the local school. After completing primary bilingual schooling in both French and Bamanan, they were able to use their competencies, although limited, for the village association board. Literacy classes in the cotton-growing region were progressively abandoned when the need for literates was met in each village, and with the crisis of the CMDT system that began at the end of the 1990s.

In this village, schooling has also been present since the colonial period, but recruitment has been irregular. For instance, during the inter-war period two boys were recruited for a newly opened school in Fana where they learned to read and write in French and became the first literates of the village. In 1974 a school was opened in a neighbouring village, and in 1979 the village acquired its own school, which was one of the first bilingual schools in the country. ${ }^{2}$ In this particular context, schooling is less associated with the possibility of gaining a formal job in the city than with its local value in finding work with the cottonproducer association.

An overview of literacy trends is provided by the survey I conducted among all households in the village: 19 per cent of adults over the age of 15 stated that they were able to read and write a letter. Broken down by language, this figure shows that 18 per cent had literacy in Bamanan, 10 per cent in French, and only a total of four individuals in Arabic. The scarcity of literate individuals in Arabic may reflect a common pattern whereby Arabic literacy is characterized by specific religious investment and only developed in a few families. It should be noted, however, that in some localities the use of Arabic extends much further (a strong case is made by Berndt 2008). The focus of this study has been on the literacy skills in French and Bamanan with regard to the local context where these languages were dominant in writing. Also relevant was my own language proficiency in these two languages and not in Arabic.

When discussing the issue of adult literacy or schooling with the villagers, the first idea generally put forward was the importance of being literate for the community. This idea strongly echoes, sometimes literally, the discourses

\footnotetext{
${ }^{2}$ Though French is the only official language of Mali, several 'national languages' (presently 13) have been acknowledged as useful for literacy classes, schooling and uses in the media. The bilingual school, especially at its beginning when the villagers I worked with went to school, was strongly oriented towards the acquisition of French.
} 
surrounding the promotion of literacy emanating from the institutions in charge of the literacy programmes. Thus, when Ba Soumaila Konaté, one of the first schooled villagers, was asked about his motivation in joining the literacy programme, he insisted that '[his] will was that the village move forward' ('ne nganiya kera dugu ka taa $n \varepsilon$ de ye koyi !'). ${ }^{3}$ Responding to the same question, another farmer used a phrase that was directly borrowed from a literacy slogan: 'The reason why I joined (the class) was because illiteracy is obscurity. If you are literate, you can sort things out yourself' ('N taakun tun ye, comme kalanbaliya ye dibi ye, ni i kalanna, i be se ka i yere nenabo'). One should note that the slogan 'kalanbaliya ye dibi ye'-illiteracy (literally: lack of education) is obscurity-relies on a metaphor signifying education as light (and thus on the broader semantics of 'Enlightenment') that has found its way into public discourses in Mali, but nonetheless conflicts with local representations of knowledge that value secrecy and obscurity. The last sentence of this quotation introduces an idea somewhat different from these general discourses: that of writing as a personal resource.

\section{Bypassing established brokers}

Throughout the interviews that I conducted, a common theme was that as soon as literacy skills were acquired they served private needs, and, more precisely, helped the writer avoid other channels of communication. The interest in writing lies in its ability to help a person 'sort things out for oneself', or 'deal with one's own business' ('s'occuper soi-même de ses affaires' in French; 'ka fenw dow nenabo i yere ye' in Bamanan).

The figure of the literacy broker, who makes his skills available to assist the community, is indeed present. But according to the literate villagers, the main value of writing is that the writer can avoid sharing certain information with others. Its strongest expression is found in an interview with a woman whom I met outside the village in the town of M'Pessoba.

Maïmouna Maïga: Quand on sait écrire, c'est nécessaire pour soi-même, puisque si tu sais écrire tu ne vas pas chez quelqu'un pour lui dire de te faire quelque chose. Toi-même tu sais ce que tu veux faire : je veux t'envoyer une lettre, ou bien je veux te faire une commission ou bien te demander quelque chose, si je sais l'écrire, je ne vais pas chez toi te dire il faut me faire telle chose. Je passe par moi-même, et j'écris et je t'envoie cela. C'est très important. Personne ne saura mon secret, si c'était à toi que je m'étais adressée, n'est-ce pas ....

When one knows how to write, it is necessary for oneself, because if you know how to write, you don't go and see someone else to ask him to do something for you. You know yourself what you need to do: I need to send you a letter, or to ask you a favour, or to ask you something. If I know how to write it down, I will not go to your place and ask you to do that for me. I go through myself, I write it and I send it to you. It is very important. Nobody will know about my secret; but if I had asked you, you see ....

This woman - who had been to school until the ninth grade, then completed a training programme as an assistant accountant-summed up in a wonderful

\footnotetext{
${ }^{3}$ Pseudonyms are used for all interviewees.
} 
phrase the shared idea that writing frees you from the usual need to go through someone else. The standard way is to 'go through' someone, and writing allows what literally appears as a short cut: 'I go through myself', meaning 'I do it myself'.

This idea recurred throughout the interviews and conversations I had with literate and non-literate villagers alike, the latter deploring that they had to ask others to write for them. From the literates' point of view, being asked to write for others had an ambiguous significance. While they were proud of the social acknowledgement of their literate status, they also resented having to share in personal stories that were none of their business or being aware of others' secrets. In referring to the domain of private writing, the terms secret in French and gundo in Bamanan were conspicuously used by my interlocutors. I would now like to focus on the notion of secrecy and its local uses in order to disentangle it from ideas of privacy and confidentiality.

At first, I thought the use of the term gundo was a translation bias in interviews in Bamanan. In the first interviews I conducted, the word was often introduced by my assistants in translating one of my questions about personal writing activities. ${ }^{4}$ Turning my question 'Do you write down personal things?' into 'Do you write down secret things?' obviously changed its meaning and, more importantly, the way I could proceed with the interview. Where pushing the question a little further would have been acceptable when dealing with private writings, it would have seemed improper to touch on any secrets. One of my interlocutors made this point clear when he stated that we should know what gundo means, indicating that he was not willing to say more about his writing. I soon recognized these ambiguities and discussed them with my assistants. I also began to ask myself sensitive questions. Going forward, in order to introduce the topic of the private side of writing practices, I made use of less precise phrases such as 'writing down one's own stuff' ('one's own business' or, in Bamanan, 'magonefenw', literally 'what someone may need') that I had picked up from previous interviews. However, it also happened quite often that my interlocutors themselves would use the term gundo to describe that part of their writings that went beyond institutional and professional demands. In some cases, the term was meant to end the discussion on the topic.

As has often been noted (see for instance Zempléni 1984), identifying something as secret is a strategic gesture: it might establish a border that one should not try to cross, or set a high price for the information beyond it. But I also encountered very ordinary uses of gundo, pointing simply to a level of privacy.

\section{Gundo as a metonym for privacy}

What appeared as a mistranslation by my assistants, turning 'personal' into 'secret', in fact reflects to a great extent the common sense of gundo as a term. The lexical field it belongs to ties it to the idea of sutura (a term derived from Arabic, conveying the notion of discretion) and opposes it to the idea of publicity: preserving gundo versus saying or doing something 'mogo nena' (literally in the

\footnotetext{
${ }^{4}$ I have been assisted mainly by two school teachers working in the village, but also, during holidays, by two students in the village.
} 
eyes of other people-openly and publicly) or 'kenc ma' (in the open). This is demonstrated in the following excerpt.

Lamine Traoré: Bon ! n be se ka a fo o koni, a nafa folofolo yere, ni i be letiri seben sisan, a

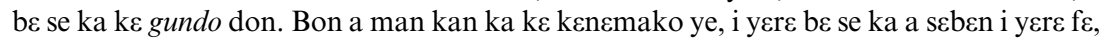
k'a soro mogo ma bo a kala ma [interview in Bamanan, translations by the assistant omitted].

Well, what I might suggest as its particular interest [referring to writing] is that when you write a letter, it can be secret. If it shouldn't be something public, you can write it by yourself, without anybody being aware about it.

This opposition between gundo and kenema structures several other discourses. Very often, gundo is used to point to a private domain, a domain of one's own, or concerns business that the speaker considers to be theirs, but may sometimes be shared with a few others. For instance, one villager used it to refer to the activity of repairing motorbikes, something that he intended to start doing but hasn't mentioned publicly yet. Writing on this topic was referred to as gundosebsn, secret writing. Along with the term's ordinary uses, gundo also designates specific domains of knowledge, which are strongly associated with power and should not be shared with others, except within the highly restricted context of interpersonal transmission. Kilisiw, magical incantations, were the most conspicuous information belonging to this kind of secret knowledge.

The word's wide range of uses fits well into anthropological descriptions of Bamanan knowledge. Barbara Hoffman, for example, provides as the overarching sense of gundo: 'anything that a speaker wishes to endow with "insider" status'. This can include the trivial but private information that one would mention in public (the topics of gossip), as well as magical knowledge carefully protected from public dissemination (Hoffman 1998: 90; see also contributions in Jansen and Roth 2000). Thus, the domain of reference of gundo is vast enough to encompass both the notion of individual or private matters, and more restricted uses referring to specific bodies of knowledge whose social transmission and public enunciation are controlled. What is common to all these cases is the way the writer draws attention to the state of restricted access to this knowledge, in opposition to writings that are public.

\section{A socially recognized sphere of private writing: the domestic as a masculine prerogative}

This shift from a community-oriented promotion of literacy to a claim for its private uses does not imply that private writing occurs without any solicitation from the outside. On the contrary, what counts as private often takes place as a response to institutional demands. These demands target some villagers, mainly the household heads when they are literate, and apply less obviously to others.

Notably, since the 1970s, the CMDT has encouraged the recording of both agricultural activities and family events by the heads of households. A model document was even designed, a carnet d'exploitation (Dumont 1973: 10, 13). This model was not known by the villagers where I have worked, but some recalled having been taught in literacy classes in the 1980s and 1990s to keep track of information mainly associated with agriculture, but also to record birth dates and 
other family events in an ordinary notebook. One informant distinguished between the 'forokunnafoni sebsn', 'document of information on the fields' and the 'dukunnafoni sebsn', 'document of information on the household'. Both could be inspected by CMDT agents. When I conducted fieldwork in the 2000s, the CMDT no longer relied on such writings and villagers were not asked for these kinds of documents. As we shall see, the notebooks kept by villagers combined familial and personal information and were not intended to be shown to outsiders. However, this practice set a model for some of the practices I investigated. Importantly, the CMDT literacy programme focused principally on the heads of households, or at least the heads of families, and thus men. This focus on men accounts for the gender bias that I observed, with men being twice as literate as women, but also with literate men and women engaging in distinct practices. While men developed writing practices at all levels (community, family, and personally), women tended to restrict their practices to their own needs, with the exception of the two or three women associated with NGOs. ${ }^{5}$

\section{TWO MEN AND THEIR NOTEBOOKS}

I turn now to two writers whose difference in status will allow for an exploration of the distinct meanings that private writing can take on.

\section{Notebook culture}

Personal writing occurs mainly in notebooks. The notebook is generally the most central writing material in the village. Not only is it the primary writing material at school, but it is also commonly used, together with various pre-print documents, in the village association as well as in any public meeting requiring writing. On these occasions, the notebooks are a collective possession, belonging to the association or the group in question. For individuals, one often-cited occasion for acquiring a notebook is at one of the 'trainings' literate villagers attend (called formations in French or kalanw in Bamanan; kalan literally means 'study'). Besides literacy classes, villagers in this region are invited to join postliteracy sessions as well as other trainings organized by the CMDT, and also by governmental agencies or NGOs. During such a training, a notebook is given out to the participants and generally only partially filled in, thus leaving some space for its owner's own needs when back home, with pages being either torn out to provide blank paper or written on.

Whether a person turns a previously used notebook into a personal notebook or buys one that is dedicated to personal writing, keeping one or several notebooks for individual needs is a frequent practice in this village. The expression 'keeping a notebook' must be understood literally as referring to the way people store this object as personal property. None of these notebooks follow the pattern of journal keeping, in the sense of a daily or at least regular writing of events. As we shall see, one notebook usually contains events spanning years, and the chronology is quite loose.

\footnotetext{
${ }^{5}$ For a further discussion of women's engagement with writing and how literacy is shaped by gendered relations, see Mbodj-Pouye 2012.
} 


\section{Corpus and methodology}

While conducting my first interviews, I didn't choose to focus on one writing practice. I conducted semi-structured interviews with those villagers who had attended literacy classes or school in order to try to get a sense of their reading and writing practices, both collective and private. I discovered that most of the literate villagers I interviewed had personal notes in notebooks, even if these amounted to no more than a few dates or a series of magical formulas. During the interview, I also asked if the person had some documents he or she was willing to share. When presented with their writings, I asked for permission to photograph some of them. The corpus I collected in this way presently consists of 651 pages of such notebooks, photographed with 25 distinct writers in the same village or in neighbouring hamlets. ${ }^{6}$ In the course of the interviews, I let my interlocutor comment on the passages he or she was willing to share. Thus, I rarely have a systematic description of the content of a notebook. My choice was not to insist on getting an exhaustive comment on a few texts - at the risk of seeming to pry into the most secret parts - but rather to get access to the wider range of practice.

Rather than providing an overview of this practice, as I have done elsewhere (Mbodj-Pouye 2010) I shall focus here on two writers. I have chosen to present and edit some of their writings because they stood out as the most prolific among the group of writers with whom I have been working. They are also among the writers with whom I have had a long-term relationship, with repeated interviews and observations going back to 2002. This is relevant since my aim is to understand the practice of writing at two levels of diachrony: with regard to both the career of a writer and the story of the notebooks. The two writers also represent distinct generations, and different social groups: Demba Coulibaly, a household head who is a respected elderly man; and Moussa Coulibaly, the youngest son in his family and a man without any community responsibilities.

\section{Demba Coulibaly's notebook: a religious and domestic compendium}

Born in 1932, Demba Coulibaly was one of the first from this village to go to school. In 1944, he was recruited for the school in Fana, the neighbouring city, where he spent five years and learnt to read and write in French. He then migrated to Côte d'Ivoire and engaged in various trading activities. After returning to the village in 1959, he was recruited in 1963 by the CFDT (Compagnie Française de Développement des Textiles) thanks to his level of literacy in French. As a local agent of the CFDT, and then the CMDT, he was trained as a literacy instructor in Bamanan during the mid-1970s. He returned again to the village after retiring in 1987. Complementing his small pension with farming, Demba is able to live quite comfortably. He is still an active member of the village association, where he acts as a secretary, and is often asked to write up collective activities or to read and write letters on behalf of others.

Although I have not directly observed the way he stores his documents, the concept of archiving nonetheless seems applicable here. Demba presented me

\footnotetext{
${ }^{6}$ I received written permission from the writers to use and reproduce their texts. To protect their privacy, I use pseudonyms for the writers. I also diguise their names on the photographs. Other personal names are not altered, as first and last names draw from a very limited stock.
} 
with documents dating back to the 1960s in a rather organized way, as he was able to access the same documents for me during each of my field trips over the years. $\mathrm{He}$ also reflected on his organizational practices, distinguishing between notebooks for work ('le service') and those that were personal. We shall see that some writings blur such a clear-cut distinction, however.

Among the six notebooks he shared with me, four were old notebooks from his training and employment at the CFDT/CMDT, dating from the mid-1960s to the 1980s. One of these also contained personal notations: following notes that were copied during a class on water treatment, he recorded two magical incantations. A similar shift in use (from collective to personal) is seen with a school exercise book from one of his sons that he has turned into a personal notebook.

One notebook stood apart as a specimen of writing material dedicated to personal notation. When I first photographed it in March 2003, it seemed quite new. I was subsequently able to see the notebook again in July 2003 and then in 2009 , when it was no longer in use. By that time, he had rescued another school exercise book with plenty of pages left for his current use. The twelve pages I have photographed from this notebook (which can be viewed as part of the online supplementary material published with this article) give a sense of the variety of themes and genres appearing in the notebooks in general. Demba had not given his notebook a descriptive title. When specifically asked about it, he simply said that it was 'un cahier de brouillon' (an exercise book). This notebook was apparently started in order to record a specific text: a prayer in Arabic, transliterated into the Latin alphabet, that covers two and a half pages. Demba told me that he had duplicated this text from a copy belonging to one of his friends in the village, who himself had copied it from the son of a well-known Islamic scholar, Mamadou Hakilidouman. The notebook had subsequently been used to record much shorter and heterogeneous notations pertaining to two primary realms: religious and magical information and family and farming activities (see the page of his notebook reproduced in Figure 1).

The notations predominantly draw from Islamic sources of knowledge, including a variety of genres and uses. Besides the opening text, one also easily identifies Qur'anic verses (the Verse of the Throne, II, 255, on p. 7, as well as XLII, 19 on pp. 9 and 12) and petitionary prayers (under the title of duga, a Bamanan word from Arabic du'a, that generally translates as 'benediction'). Other shorter notes record useful phrases to repeat when telling one's beads (or wird in the West African Islamic tradition). ${ }^{7}$ Demba's general comment about these notations was, 'Since I am old now, I pray and tell my beads.' In these texts, the Arabic language appears in Latin-based transcription, and instructions are given in French, notably the number of times the prayers should be recited. ${ }^{8}$ The source for these texts is either personal acquaintance, as in the case of the opening text, or a printed text. ${ }^{9}$ Interestingly, one of the notations is reworked a

\footnotetext{
${ }^{7}$ The Bamanan form is generally used as a verb: $k^{\prime} a$ wurudi, to tell one's beads. It derives from the Arabic noun wird, which refers in the region to a Suni litany (Soares 2005: 37).

${ }^{8} \mathrm{~A}$ thorough analysis of code switching in the corpus of notebooks as well as in other vernacular texts is provided in Mbodj-Pouye and Van den Avenne (2012).

${ }^{9}$ Demba owns Amadou Tall's Dimensions de l'Islam: Selon le Coran et la Sounnah, $5^{e}$ édition Revue, Corrigée et Augmentée (1995-6), and mentioned it as one of his sources - but it doesn't
} 


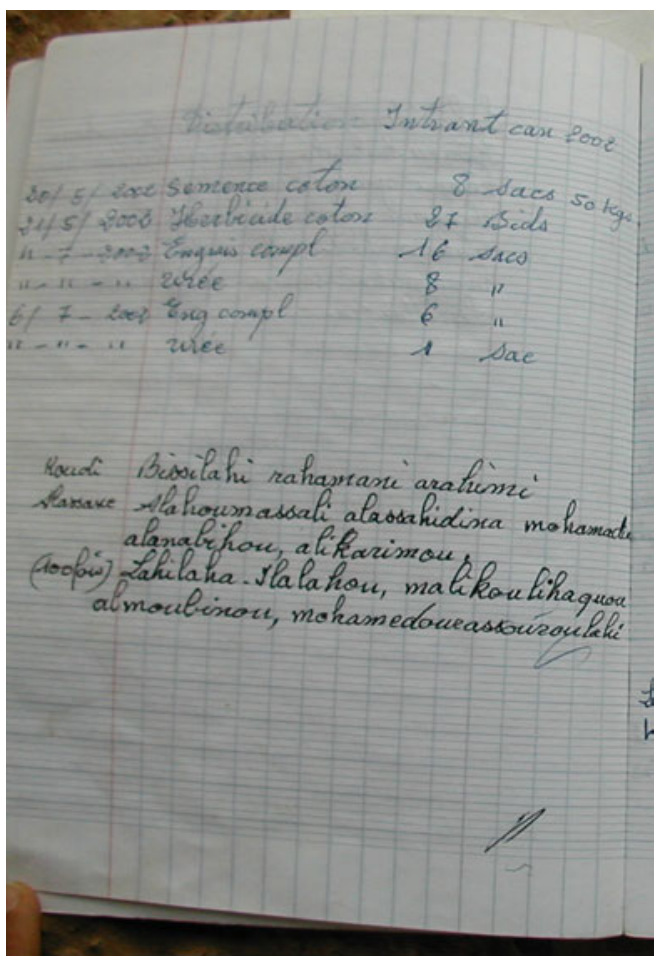

\begin{tabular}{|c|c|c|c|}
\hline \multicolumn{3}{|c|}{ Transcription } & Translation \\
\hline \multicolumn{3}{|c|}{$\begin{array}{l}\text { Distribution Intrant can (common abbreviation } \\
\text { for campagne] } 2002\end{array}$} & Distribution inputs for 2002 campaign \\
\hline 20/5/2002 & Semence cotton & 8 sacs $50 \mathrm{kgs}$ & Cotton seed $850 \mathrm{~kg}$ sacks \\
\hline $21 / 5 / 2002$ & Herbicide cotton & 27 Bids [bidons] & Cotton herbicide 27 cans \\
\hline $1117 / 2002$ & Engrais compl[exe] & 16 sacs & Complex fertilizer 16 sacks \\
\hline “_”-" & Urée & $8 ”$ & Urea 8 sacks \\
\hline $6 / 7-2002$ & Eng[rais] compl[exe] & $6 "$ & Complex fertilizer 6 sacks \\
\hline “_,"-" & Uree & $1 \mathrm{sac}$ & Urea 1 sack \\
\hline \multicolumn{4}{|c|}{ Roudi Alassane [a wird with this title] } \\
\hline \multicolumn{4}{|c|}{$\begin{array}{l}\text { Alahoumassali alassahidina mohamadu alanabihou, alikarimou. } \\
\text { (100 fois) /(100 times) Lahilaha-Ilalahou, malikoulihaquou almoubinou, } \\
\text { mohamedourassouroulahi }\end{array}$} \\
\hline
\end{tabular}

\section{FIGURE 1 Page 6 of Demba's notebook}

few pages later. On page 9 , the first mention of the petitionary prayer titled 'Latifou' provides the prayer before the Qur'anic verse it is related to, while its second reference (p. 12) gives the usual order, with the Qur'anic verse first and

appear to be the direct source for any of his notations, as the transliteration is slightly different from the one he uses. 
then the prayer. These notations are oriented towards direct personal use; they seem to form a portable and personalized compendium for Demba's regular consultation. This individualized way to relate to Islamic knowledge echoes the transformations of other Islamic practices and knowledge in other media, such as radio and audio-tapes (Schulz 2006).

Along with these texts, which fit well with Demba's self-presentation as an elderly pious man, the notebook also displays three incantations (kilisiw) in Bamanan, collected through personal contacts. Such incantations also appear in another of his notebooks, where they are entitled, in a phrase borrowed from Arabic, 'Bismillâhi'; the opening word of the utterance and the indication for its use are in French: 'Récité dans l'huile et masse sur le ventre avec trace croize + sur le dos' ('To recite on oil and massage on the belly while tracing a cross + on the back'). As Demba did not comment on this page when we went through his notebook together, I am not able to explain the exact meaning or use of the formula. It is important to point out, however, that such writings can also be found along with Islamic texts. ${ }^{10}$ The same orientation towards personal use is evident, with precise instructions being given or following the full text of the formula.

Throughout the notebook, other entries also appear that deal with profane topics. Thus, some unidentified calculation appears on p. 4, in addition to the farming records on p. 6; the address of a relative is given on p. 9; family accounting, probably linked to a ceremony, occupies p. 10; and the date where some fields were sown is recorded on p. 13. Page 11 features a particularly interesting text that provides a wider sense of the use of the notebook. At the top of the page Demba utilizes the form of the legal contract to register an agreement with a Fula herdsman who had taken charge of his cattle. This type of text comes up frequently in the notebook, since villagers often rely on pastoralists to take their cattle to graze in far-off locations for months, and on this same page two are recorded. The first one is particularly detailed, with dates being given from both the civil calendar (the Gregorian calendar in use in Mali) and the 'Bamanan' moon-based calendar, along with translations from French to Bamanan, and a signature by Demba. ${ }^{11}$ Since the validity of this text as testimony in a legal context is doubtful (if the form of the contract had been strictly followed, the herdsman would have signed too, or there would have been witnesses involved), it is clear that Demba is using this formal pattern for other ends: he wants to imbue an ordinary piece of writing with a sense of seriousness, and act out the role of a literate man. Even though the notebook is neither circulated nor read aloud publicly, the attention given to self-presentation is clear.

As a whole, Demba's notebook appears to be a useful tool for everyday records, from his personal investment in Islamic and Bamanan knowledge to the management of his farm and family. As an elderly man, he presents himself as

\footnotetext{
${ }^{10}$ The continuum between the two domains of knowledge identified as 'Bamanan' (traditional) and 'Mori' (Islamic) is a classic theme of Mande anthropology; see Bazin 1985; Soares 2005. Working in the Segu region, C. Barrière has demonstrated that magical practices integrate elements from both horizons (Barrière 1999).

${ }^{11}$ This calendar is locally called farafin ('African') or 'Bamanan'. Some names for months refer explicitly to seasonal activities, thus indicating that this calendar was in the past somehow fixed according to the annual cycle. However, it has been brought into correspondence with the Islamic calendar, which it now follows.
} 
someone who is very religious (although making use of 'Bamanan' knowledge) and intellectual, while also still keeping an eye on his household.

\section{Moussa Coulibaly: youth culture and personal improvement through writing}

Born in 1977, Moussa Coulibaly was the youngest son of the former chief of the village. He completed his education at the village primary school, but did not pass the final exam enabling primary students to pursue further study. After leaving school, he practised seasonal migration for several years (among his diverse experiences, he delights in recalling his trips by bicycle to Guinea to smuggle cigarettes). His marriage was not approved of by his family, and he lived for some years in Koutiala with his wife, where he worked at a garage for truck repair. Finally, he was called home by his father. He accordingly returned to the village in 2001 with his children and his wife, who by then seems to have been accepted. As the youngest son of an important family, Moussa suffered from control by his numerous older brothers. Since his return, he had left the village several times for a couple of months, very often without the permission of his elder brothers. I observed that Moussa, unlike Demba, had rarely been provided with any responsibilities at the community level. He belonged to a generation that came to be literate after most of the positions in the village associations were already occupied, either by the first men who went to literacy classes in the 1970s and 1980s, or by the first schooled villagers who completed school at the end of the 1980s or early 1990s. This left Moussa Coulibaly and his peers with few opportunities to see their skills valued by the community. He was never called for post-literacy trainings, and thus had no institutional support in his writing practice. As he was not the first literate in the family, he was not in charge of important family records. His contribution, therefore, at the family level was somewhat marginal. He recorded, for instance, the weight of cotton collected individually by family members, mostly women, so that each member could be compensated correctly. He also wrote a weekly shopping list of the goods he was asked to buy at the market in Fana for other family members. He wrote down the credits taken for the little shop he managed on behalf of one of his brothers, as well as records relating to his male peer group. Moussa thus acted informally as a literacy broker in his family and the peer networks in the village. His personal writing practices were also intense: he kept several notebooks where his notations (credits, family cotton records) were mixed with prayers copied in Arabic, along with incantations collected from friends and football results. He kept his individual notebooks in several places in his room. Some notebooks and documents were piled together with books; some were stored in small plastic bags. Some smaller notebooks were kept together with a rubber band. The smallest fitted into his wallet. A print calendar was also hung on his wall, where he marked events by crossing the relevant date.

Most of the practices Moussa Coulibaly engaged in were not oriented toward dealing with institutions or social actors coming from outside the village. On the contrary, he was part of local networks where writing and reading play some role. This testifies to the local value of literacy, beyond its importance in coping with administrative and institutional demands, something that is often underestimated when literacy levels are assessed in this area (see notably Dombrowsky, Dumestre and Simonis 1993). 
Moussa was less organized in his writing practices than Demba, and all his notebooks bore similar notations, though some were more oriented to collective uses than others (one was mostly for the youth association to which he belonged). The notebook I will focus on he entitled 'Cahier de contrôle' ('Control notebook'). As in Demba's case, it was his current notebook when we first discussed his practice in August 2002 and I took a few photographs. As Moussa and I became friends, I had many more conversations with him, and he often brought his notebooks for me to examine. (In fact, he asked me to 'control' them, and it has been difficult for me to explain that my interest in reading them was different.) I subsequently saw this notebook again in 2003, and partially photographed it, and then again in 2004, when I actually photographed the whole notebook. In such a case, one wonders if the ethnographic relationship transformed or intensified the practice. Certainly, I think my interest in Moussa's notebooks might have encouraged him to develop his writing. However, I would also argue that this does not apply to this notebook, which was almost full when I first saw it. Even in regard to the texts that he wrote afterwards, our relationship had only minimal influence on his practices. For instance, Moussa kept shopping lists for me that he would have thrown away and he wrote my address on the first page of a notebook that I offered him. Nonetheless, the whole content of his notebook is quite similar to what he wrote prior to my coming to the village.

The title of the cahier de contrôle refers to his initial use of the notebook. On three pages at the beginning (pp. 3-5), he recorded credits granted to others when buying goods in the town and selling them to other villagers. It is a title he used for at least one other notebook. I will first briefly sketch out the content of the notebook before providing an analysis.

After the credit section, pages 6-7 display a complex calculation regarding the cotton harvest within the family. During the harvest, those who contribute receive money in proportion to what they collect. The payment is made afterwards, when the whole amount of the cotton collected by the family has been weighed by the village association, and then gathered and picked up by the CMDT trucks. This record is distinct from the information the village association keeps track of, since it concerns the internal allocation of the profit. The names are mainly those of women from the compound, as well as two other men. The aim of this rather elaborate calculation is to establish the amount that each of the participants should be given. Page 9 offers a list and some unidentified calculation.

Pages 10 to 15 were composed during a single week, from 26 August 2003 to 1 September 2003. The text is a written copy of an Islamic booklet, probably French-Arabic, and here reproduced in Arabic using the Latin alphabet. On page 10 , the aspects of a $r a k^{\prime} a$, the basic unit of the Islamic prayer, are provided: the first sura of the Qur'an, Al-Fatiha, and other prayers are to be said in distinct positions. The other pages continue with the last suras of the Qur'an (which are generally the first to be taught after Al-Fatiha). These pages stand out because they are written in green ink, which is a way for the writer to isolate this religious section within his notebook. Since Moussa has adopted the school habit of beginning with the date whenever he writes, we can see he had written almost every day, until, in the middle of one sura, he stopped.

Following the order of the notebook, its next section brings us back in time, since it dates from April 2002. Moussa left some empty space, but as I have not questioned him about it, I cannot say whether he had in mind adding to the 


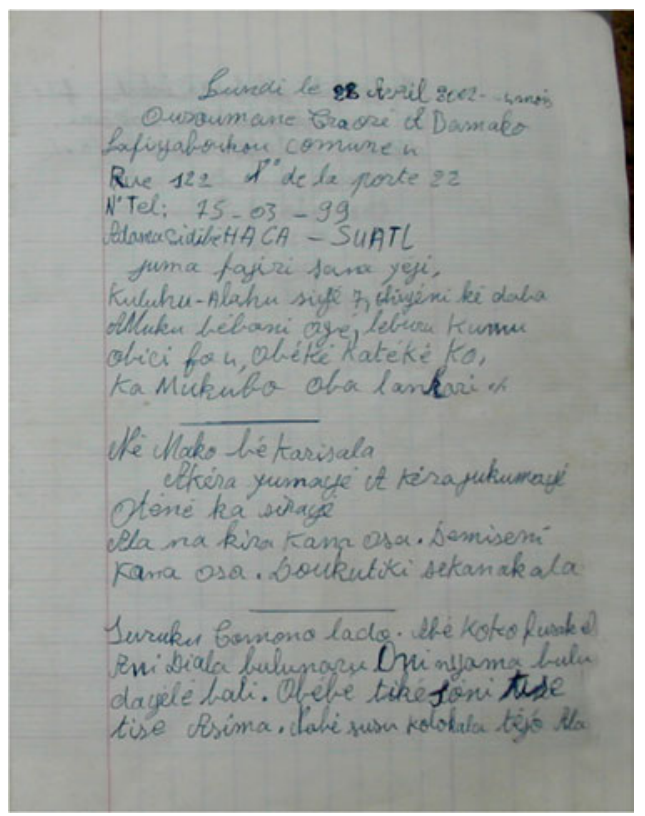

FIGURE 2 Page 19 of Moussa's notebook

prayers he had copied or something else. As in Demba's notebook, the commingling of strictly religious and magical notations is evidenced on pages 19 and 20 (Figure 2).

In commenting on these texts, Moussa Coulibaly presented the first as a dalilu, a 'magical means' (see McNaughton 1982 for a precise definition) for women who have abundant periods. The second is a kilisi, whose use Moussa has not explained to me. Finally, a medicine (bamanan fura) and its fabrication process are given. Again, Moussa did not explain its therapeutic function.

The following page (after one that has been torn out) consists of credits, which, according to Moussa, were taken down while he was in Bamako. Finally, he has recorded the results of a series of Africa Cup of Nations football matches in Mali that he listened to on the radio in 2002. A drawing of a bus is the last item in the notebook.

This overview shows that Moussa's notebook has some similarities with Demba's. This impression is confirmed when reading through the notebooks, for one gets the sense that their heterogeneity is balanced by an underlying common aspect. They draw from the same limited repertoire of genres: prayers, magical incantations, addresses, accounts, family events, information from the radio. They also share an element of compilation, being more or less organized. Some idiosyncrasies do emerge, however, regarding the personal profiles of the writers. Here, football results provide a glimpse into practices linked to youth culture that other villagers, like those studying in town, develop further still. In another notebook, Moussa also writes down and collects the titles of songs he has 
Transcription / Translation

Lundi 22 Avril 2002 - 4[e] mois/Monday [22 April 2002]

[An address in Bamako. Another name and initials.]

[This is followed by a text - translated below - described by Moussa as a dalilu, a magical device prescribed to relieve a woman with an abundant period.]

At dawn on Friday, the resin of the gum copal tree,

'Qul huwa Allahu' [Sura 112] 7 times, the weeding hoe,

it's the one which one uses to extract the powder. The small green lemon,

it's chopped, and used to wash your hands; you extract the powder which serves as an antidote.

[Moussa described the following text, translated below, as a kilisi, a magical incantation or spell.]

I need so and so.

Whether for good, whether for bad

I don't care.

May God and His Prophet not die from it.

May the little child not die from it. May the village chief not be involved.

[The last text on this page was presented as a bamananfura or traditional medicine. It is continued on the following page: below is a translation of the whole text.]

The mistletoe of the Buffalo thorn. That is what is used to cure it.

As well as the green leaves of the African mahogany, and the leaves of the wild bauhinia impossible to open. One should cut all of them at home, if you can't, you can't get to the seed.

While crushing it, the pestle should not stop.

Once crushed, one should put hot water in the calabash,

when cooled to the point one can drink it,

some part of it is taken to be drunk, the rest you use to wash yourself.

heard on the radio in order later to have a pirated compilation recorded. What distinguishes Moussa most clearly is his intense engagement with writing, even though he faltered at some point in his daily writing of prayers. Clearly, he utilized writing in many of the activities he engages in on a daily basis. He consciously tried to improve his writing (he often asked that I correct his orthography) and, what's more, seemed to believe that these practices would offer him some opportunities in the village or elsewhere.

\section{FIGURES OF THE SELF}

The foregoing presentation suggests that locating within the writings what is 'personal' is not straightforward and, further, does not point to the notion of a psychological interiority as it is understood in the Western sense. To disentangle the different meanings the notion of 'personal' covers, I borrow a set of distinctions from Michel Foucault in his elaboration on the idea of 'individualism' in The Care of the Self, the third volume of his History of Sexuality (Foucault 1984). 


\section{Delineating the private and marking borders}

First, the focus on the personal can lead to a survey of the themes of writing in search of 'private' issues. As we know from historical scholarship, writing played a prominent part in the way the colonial power controlled populations and individuals (Hawkins 2002). As a 'technology of the individual' (Foucault 2001), writing made its impact through identification procedures, ranging from birth registers to individual ID papers. Personal writings designed in response to these official writings appear in the notebooks with a more or less close resemblance to these assigned models.

In this sense, keeping a personal counterpart of imposed writings, such as amounts of cotton or birth records, is a way to engage with figures of the subject that are imposed by institutions. It opens a space where these assigned identities can be negotiated. For instance, introducing the Bamanan calendar is a way to maintain the importance of this reference, to provide it with a status that it does not receive on any official occasion. This point highlights the importance of translation, which, as Derek Peterson has demonstrated, is a creative and popular activity (Peterson 2004). We can go further and identify instances where the tokens of officialdom, such as stamps and signatures, are consciously diverted for self-presentation, for instance in Demba Camara's notebook quoted above where a page mimics a contract. As Karin Barber notes in another context 'the diary is ... a site in which Boakye Yiadom ... stiffens up the outlines of his self with the carapace of officialdom' (Barber 2007: 198, commenting on Miescher 2006). The line between private and public thus appears to be redefined by the writers through their practices, though in disparate ways according to the writer's age and gender.

\section{Renegotiating access to bodies of knowledge: secret versus public}

The second sense of individualism that Michel Foucault distinguishes concerns the valorization of the individual. This echoes traditional views on individuality, which are particularly associated with the figure of the hero. In their analysis of the figure of the hero in the Mande world, Charles Bird and Martha Kendall insist on the association of the individual and the secret knowledge from which he draws his strength (Bird and Kendall 1987). ${ }^{12}$

Writing opens a vast new terrain for more individualized relationships to bodies of knowledge whose public utterances are strictly controlled, and which count as gundo in the strictest sense. Of course, writing conveys a certain risk of dissemination. More importantly, writing, as it separates the utterance from its social context of transmission and enunciation, may appear inadequate for the transmission of secrets (Jansen 2003: 185-9). This played a role in the

\footnotetext{
${ }^{12}$ Bird and Kendall indicate that this figure has acquired new forms. 'Socialization recapitulates much of what we have discussed here. Raised in large and extremely close-knit families, youths nevertheless learn that their culture lavishes esteem and adulation on its rebels. The figures preserved in history are those who broke with the traditions of their village, severed the bonds of badenya, travelled to foreign lands searching for special powers and material rewards, but just as importantly, they are also the ones who returned to their villages and elevated them to higher stations. This image of the rebel hero who breaks with, but ultimately returns to his people is not without relevance to the modern Mande child' (1987: 22).
} 
ethnographic relationship with the people I interviewed, as some writers explained to me that they agreed to let me see their incantations because they knew that I could not do anything with them. A secret that is detached from the conditions of its transmission loses its value. But precisely because the notebook is a personal belonging, the writer has some control over the transmission of the secrets he records in it. For those who choose to write down 'secrets', the concern is to make sure they keep their notebooks out of reach of others, and this may involve employing cryptic strategies (in the form of abbreviations or use of a specific language).

The importance of collecting, especially with regard to formulas and incantations, but also in the case of religious and historical knowledge, suggests that these texts are also sites where knowledge is transformed. As we have seen, collecting magical incantations and medicinal recipes and writing them down in a notebook is one of the villagers' favourite uses of writing, popular among men and women. In this instance, writing appears to be a way of bypassing established brokers, and of giving unauthorized writers a space for themselves. Admission to this realm of privacy is restricted to those with whom the writer has decided to share his notebook. Other sensitive matters pertain to local history. The scarcity of writings on this topic is due to the fact that the village where I have been working was founded by families with a slave background, which is typically a 'public secret' - widely known but never spoken of publicly. The two villagers who have admitted to keeping notes on the foundation of the village have never agreed to share them.

This perspective can be broadened to include notations that are not at the core of what is locally understood as secret. For instance, Islamic knowledge, even when it comes to canonical prayers, is reworked in singular ways by the writers, who create their personal compendia. ${ }^{13}$ Even overtly public information, such as football results broadcast on local or international radios, gives way to practices of recollection aiming at creating one's own universe of reference.

\section{Techniques of the self}

This leads to Michel Foucault's third characterization of individualism, which concerns the intensifying of ways that one can relate to oneself. The 'personal' can be located in the expressive ways of creating a space of one's own. This goes along with specific practices, such as giving a title to a whole notebook if it is dedicated to personal writing. Of course, relating to oneself does not imply any kind of solipsism: as commonly acknowledged, the self is constituted through a 'complex process of interaction of multiple practices of identification external and internal to a subject' (Behrend 2002: 47, quoting Friedman 1993). In fact, the writers rely heavily on borrowed models.

Two dimensions of this process of borrowing must be taken into account. First, the available models are often those that are imposed upon the villagers.

\footnotetext{
${ }^{13}$ Given my lack of expertise in the domain, the analyses on the Islamic content of the notebooks are necessarily provisional and aimed at inciting further research on ordinary appropriations of Islamic texts in Mali, in the wake of studies of Islamic culture in contemporary Mali such as Brenner (2001) and Soares (2005).
} 
This makes taking hold of them especially meaningful as a way of reversing a situation to one's own advantage (this is strikingly apparent in Demba's contract). Second, 'borrowing from' also conveys a sense of 'belonging to'. The personal notebook appears as a site for self-projection in arenas that exceed the village boundaries. Participation in youth culture is strongly asserted in some notebooks, through sports results and titles of songs, providing an instance of the logic of 'extraversion' that has been cast as characteristic of African modernity (Bayart 2000). The insertion in global cultural circuits is facilitated by other media (notably the local radio), and also draws upon local bodies of knowledge. The ordinary imagination of villagers, especially the youth, puts together these different social arenas.

Along with this dimension of self-projection, notebooks also record events, though without involving the self-scrutiny that has been associated with the development of the modern self. As noted above, writing is not dictated by the injunction of reflecting on one's daily deeds and feeling, as in the practice of journal keeping spread in other contexts by Christian missionaries. Most notebooks include more family events than Demba's and Moussa's, but they follow the same pattern of very heterogeneous notations loosely organized, and events are recorded without the writer commenting on them.

\section{CONCLUSION}

A superficial look at the documents presented might easily deny them any intellectual aspect: their appearance is messy, with notations spanning years yet kept in a single notebook, testifying to the irregularity of the writing practice; the only lengthy texts are actually copied from other print or handwritten sources, thus discouraging the search for original creations. I hope that the thorough investigation undertaken in this article will invite other readings of such personal writings, which one is likely to encounter anywhere in Africa.

The detailed analysis of the texts combined with ethnographic data has produced two main results that I wish to highlight here. First, these practices bear witness to the intellectual activities engaged in by the owners of the notebooks. Even the act of copying is important: it should not be dismissed as mere repetition, since it involves finding rare print or handwritten sources, selecting the texts that one wishes to make use of or remember, and then spending time reproducing them. More generally, the notebooks display modes of organization-Demba numbering his kilisiw, or Moussa distinguishing by page breaks or horizontal lines different spaces for distinct topics on a single page. As students of writing cultures know well, handwriting offers many graphic resources that even moderately literate writers mobilize so as to create an order. Furthermore, following the writing practices diachronically one gets a sense of the experimental nature of the practice, with the reworking of the same text occurring in both examples, and indeed being a recurring feature of the general corpus. Even unfinished endeavours, such as Moussa's copying of Qur'anic texts, point to the way writers explore the possibilities offered by literacy.

Second, the notebooks draw their value from the sense of privacy attached to this practice. The personal notebooks stand out as distinct from all other 
community documents that are subject to control and supervision. They offer the writer a way of delineating a world of one's own, putting together figures of the self without necessarily providing a view of the united self. Thus Demba records three kilisiw pertaining to the Bamanan domain of traditional knowledge in the middle of a notebook mainly devoted to the Islamic knowledge he more readily recognizes as his main interest. Moussa, for his part, puts together notations taken while migrating to Bamako, as well as managing family and personal accounts, along with football results. That all this is important and makes sense to him was evident to me from the pleasure he always took in going through his notebooks with me. Thus, even for people whose literacy level is relatively low, accounting, writing and reading practices open a space for self-management as well as intellectual activity. Literacy is not only imposed upon rural Africans in a harsh and sometimes humiliating manner (see a strong case in Piot 2010: 139-43); its individualizing character is also captured by them in order to delineate a space of one's own in creative ways.

This issue of creativity opens up a last question, that of the emergence of a genre as a stabilized and transmittable form. As we have seen, this practice is not labelled in any specific way. From my research, I did not witness any case of the transmission of this practice within the family. Since this habit of keeping a notebook developed against collective practices developed by the CMDT from the mid-1970s to the 1990s, when it was still an important economic and social actor, and given the decline of literacy classes and formations, my guess is that the model of self-managing it diffused will lose its shaping power. Other models, such as school-based formats or the distinct record-keeping demands of each NGO, will find their way, perhaps providing more direct guidance to self-writing than the experimental and open-ended practice I have studied.

\section{ACKNOWLEDGEMENTS}

This article draws on my $\mathrm{PhD}$ research at University Lyon 2, funded by a French Ministry of Research grant (2002-7), as well as an additional research trip supported by the Centre d'études africaines (EHESS, Paris). A first version of the text was presented in November 2008 at the University of Toronto, and I thank Sean Hawkins for inviting me. Writing was completed in 2010 at Zentrum Moderner Orient, Berlin, where I benefited from support for editing and valuable comments. I am most grateful to Gérard Dumestre, Cécile Van den Avenne, Kristin Vold Lexander and Francesco Zappa for their valuable help with the transcriptions and analysis of the texts. All my thanks go to the writers who gave me access to their personal writings and permission to reproduce them.

\section{SUPPLEMENTARY MATERIAL}

Supplementary material relating to this article is available via the journal's website, $<$ http:/l journals.cambridge.org/AFR $>$. This comprises photographs together with transcriptions and translations from Demba Coulibaly's notebook - photographed in March 2003 (pages 1-11), and July 2003 (pages 12-13), labelled with file names Demba Photos 1-8; and from Moussa Coulibaly's Cahier de contrôle-photographed in April 2004, labelled with file names Moussa Photos 1-16. 


\section{REFERENCES}

Barber, K. (ed.) (2006) Africa's Hidden Histories: everyday literacy and making the self. Bloomington IN: Indiana University Press.

— (2007) The Anthropology of Texts, Persons and Publics: oral and written culture in Africa and beyond. Cambridge: Cambridge University Press.

Barrière, C. (1999) 'Techniques d'agression magique en pays bamana (région de $\mathrm{Segu}, \mathrm{Mali}$ ): emprunts réciproques entre islam et religion traditionnelle', Journal des africanistes 69 (1): 177-97.

Bayart, J.-F. (2000) 'Africa in the world: a history of extraversion', African Affairs 99 (395): 217-67.

Bazin, J. (1985) 'A chacun son Bambara' in J.-L. Amselle and E. M'Bokolo (eds), Au cour de l'ethnie: ethnie, tribalisme et état en Afrique. Paris: La Découverte.

Behrend, H. (2002) "I am like a movie star in my street": photographic selfcreation in postcolonial Kenya' in R. Werbner (ed.), Postcolonial Subjectivities in Africa. London: Zed Books.

Berndt, J. (2008) 'Closer than Your Jugular Vein: Muslim intellectuals in a Malian village, 1900 to the 1960 s'. PhD thesis, Northwestern University.

Bird, C. S. and M. B. Kendall (1987) 'The Mande hero: text and context' in I. Karp and C. S. Bird (eds), Explorations in African Systems of Thought. Bloomington IN: Indiana University Press.

Brenner, L. (2001) Controlling Knowledge: religion, power, and schooling in a West African Muslim society. Indiana IN: Indiana University Press.

Chakrabarty, D. (1992) 'Postcoloniality and the artifice of history: who speaks for "Indian" pasts?', Representations 37 (Special Issue: Imperial Fantasies and Postcolonial Histories): 1-26.

Chartier, R. (1986) 'Les pratiques de l'écrit' in P. Ariès and G. Duby (eds), Histoire de la vie privée. Paris: Le Seuil.

Comaroff, J. L. and J. Comaroff (1991) of Revelation and Revolution: Christianity, colonialism, and consciousness in South Africa. Chicago IL: University of Chicago Press.

Dombrowsky, K., G. Dumestre and F. Simonis (1993) L'alphabétisation fonctionnelle en bambara dans une dynamique de développement: le cas de la zone cotonnière (Mali-Sud). Paris: Agence de Coopération Culturelle et Technique (ACTT), distributed by Didier Erudition.

Dumont, B. (1973) L'alphabétisation fonctionnelle au Mali: une formation pour le développement. Paris: Unesco.

Foucault, M. (1984) Histoire de la sexualité, Tome 3. Le souci de soi. Paris: Gallimard.

- (2001) 'La technologie politique des individus' in Dits et écrits II, 1976-1988. Paris: Quarto Gallimard.

Friedman, J. (1993) 'Being in the world: globalization and localization' in M. Featherstone (ed.), Global Culture: nationalism, globalization and modernity. London: Sage.

Hawkins, S. (2002) Writing and Colonialism in Northern Ghana: the encounter between the LoDagaa and 'the world on paper', 1892-1991. Toronto: University of Toronto Press.

Hoffman, B. G. (1998) 'Secrets and lies: context, meaning, and agency in Mande', Cahiers d'études africaines 149: 85-102. 
Hoggart, R. (1957) The Uses of Literacy: aspects of working-class life with special reference to publications and entertainments. London: Chatto and Windus.

Jansen, J. (2003) Epopée, histoire, société: le cas de Soundjata, Mali et Guinée. Paris: Karthala.

Jansen, J. and M. Roth (eds) (2000) 'Secrets and lies in the Mande world', Mande Studies 2 (special issue).

Mbodj-Pouye, A. (2010) 'Keeping a notebook in rural Mali: a practice in the making' in D. Barton and U. Papen (eds), The Anthropology of Writing: understanding textually-mediated worlds. London: Continuum.

(2012) 'Le genre du privé: pratiques d'écriture personnelles et domestiques dans la région cotonnière du Mali', L'Homme 203-204 (3): 321-45.

Mbodj-Pouye, A. and C. Van den Avenne (2012) 'Multilingualism in vernacular texts in present-day Mali: written language repertoires, graphic resources and discursive strategies' in M. Sebba, S. Mahootian and C. Jonsson (eds), Language Mixing and Code-Switching in Writing: approaches to mixedlanguage written discourse. London: Routledge.

McNaughton, P. R. (1982) 'Language, art, secrecy and power: the semantics of Dalilu', Anthropological Linguistics 24 (4): 487-505.

Miescher, S. (2006) “"My own life": A. K. Boakye Yiadom's autobiography - the writing and subjectivity of a Ghanaian teacher-catechist' in K. Barber (ed.), Africa's Hidden Histories: everyday literacy and making the self. Bloomington IN: Indiana University Press.

Peterson, D. R. (2004) Creative Writing: translation, bookkeeping, and the work of imagination in colonial Kenya. Portsmouth NH: Heinemann.

Piot, C. (2010) Nostalgia for the Future: West Africa after the Cold War. Chicago IL: Chicago University Press.

Schulz, D. E. (2006) 'Promises of (im)mediate salvation: Islam, broadcast media, and the remaking of religious experience in Mali', American Ethnologist 33 (2): 210-29.

Soares, B. F. (2005) Islam and the Prayer Economy: history and authority in a Malian town. Ann Arbor MI: University of Michigan Press.

Street, B. (ed.) (2001) Literacy and Development: ethnographic perspectives. London: Routledge.

Turritin, J. (1989) 'Integrated literacy in Mali', Comparative Education Review 33 (1): $59-76$.

Watson, R. (2006) "WWhat is our intelligence, our school-going and our reading of books without getting money?" Akinpelu Obisesan and his diary' in K. Barber (ed.), Africa's Hidden Histories: everyday literacy and making the self. Bloomington IN: Indiana University Press.

Zeitlyn, D. (2005) 'The documentary impulse: archives in the bush', History in Africa 32: 415-34.

Zempléni, A. (1984) 'Secret et sujétion: pourquoi ses "informateurs" parlent à l'ethnologue?', Traverses 30-31: 102-15.

\section{ABSTRACT}

In a comparative perspective, literacy has been closely associated with techniques of the self and with the emergence of modern subjectivities. But what happens when literacy is developed without genres such as diary keeping being 
widespread? Scrutinizing grassroots practices, this article demonstrates that even people who are not confronted with established forms of self-writing engage with literacy in ways that bear an imprint of their lives and subjectivities. Drawing on an ethnographic study in one village in southern Mali, it sets a socio-historical background where writing practices arise primarily as responses to the pressure of rural management. Yet the local discourses on the value of writing are suffused with notions of privacy. The article focuses on the unstable but shared practice of keeping a notebook for farming as well personal notations. Through a detailed analysis of two notebooks, it advocates for a set of distinctions between the individual, the private and the self that helps disentangle the issue of writing and self. This leads to a contrasted view of the local engagements with literacy. The question of the crystallization of notebook keeping as a genre remains open.

\section{RÉSUMÉ}

Dans une perspective comparatiste, l'écriture a été étroitement associée au développement de techniques de soi et à l'émergence de formes modernes de la subjectivité. Mais qu'en est-il quand l'alphabétisation n'est pas accompagnée par la diffusion de genres tels que celui du journal ? Cet article se propose d'examiner des pratiques d'écriture locales qui se sont développées en l'absence de formes établies de l'écriture de soi ; même dans ce cas, les pratiques d'écriture qui émergent marquent de leur empreinte les trajectoires des scripteurs et modèlent leur subjectivité. S'appuyant sur une enquête ethnographique dans un village du sud du Mali, cet article présente ce contexte socio-historique où les pratiques d'écriture sont d'abord des réponses aux demandes des institutions en charge de l'encadrement rural. Pourtant, selon les discours recueillis localement l'intérêt de l'écrit est d'abord d'ordre privé. Cet article s'intéresse plus particulièrement à une pratique peu stabilisée mais partagée, celle de tenir un cahier pour les activités agricoles comme pour des notations personnelles. L'analyse détaillée de deux cahiers permet de faire ressortir la nécessité d'une série de distinctions entre l'individuel, le privé et le soi, qui permet de déplier la question du lien entre écrit et rapport à soi selon ces différentes dimensions. Cela ouvre à une analyse des engagements dans l'écrit dans leur diversité. La possible cristallisation de la pratique de tenir un cahier en un genre reste ouverte. 